\title{
Design and Practice of Multi-level Project Driven Teaching Mode in Database Application
}

\author{
Jing Lin \\ School of Mathematics and Computer Science, Wuhan Polytechnic University, Wuhan,China \\ whpu_linjing@163.com
}

Keywords: multi-level project driven; teaching mode; practical teaching

\begin{abstract}
This paper presents a multi-level project driven teaching mode in the "database application" course. The new teaching mode is based on the development and implementation of multiple projects. The projects involve the virtual management information system, real application system and business projects in enterprises. With the development of projects, there are great changes in the teaching contents and teaching process. Practical teaching is critical in the new teaching mode. Results show that the teaching mode motivates students' learning passion, increases their comprehensive abilities, and improves teaching efficiency.
\end{abstract}

\section{Introduction}

The database application is the required course of Information Management Major in most colleges. The course extends the knowledge of database principles. In this course, students learn how to develop application system with a database management, such as Microsoft SQL Server, Oracle.

In this course, practice is important. Many disadvantages of traditional teaching mode may lead to poor teaching effects. The paper analyzes current teaching situations and presents a multi-level project driven teaching mode. Different from the teachers' instructing mode, the multi-level project driven teaching mode changes students' passive learning habits. In the development process of the project, students not only master knowledge, but also improve self-learning abilities.

\section{Current teaching situation}

There are some problems in current teaching of the database application course.

(1)The teaching contents are short of changes.

Now the teaching contents mainly depend on textbooks. But some knowledge rarely appears in textbooks. If teachers only teach according to textbooks, the contents are not enough and short of changes.

(2)The teaching method is old.

With traditional teaching methods, teachers usually explain knowledge to students in classroom. In this way, students feel the course is boring. So they are often not interested in this course and study passively. These all lead to bad teaching effects.

(3)Practice is less.

In current teaching activities, experimental class hours are limited. Most of experiments are verified. It's bad to develop the students' thinking and practical abilities.

\section{Multi-level project driven teaching mode}

Teaching idea. Based on the constructivism theory, a new teaching method is gradually popular in recent years. This is the project-driven teaching method. The idea of project-driven teaching is the implementation of a project in teaching activities.

In the database application course, we introduce the project-driven teaching method. The implementation of multiple level projects is the core of teaching activities. Practice is very important for the multi-level project driven teaching mode. Besides validating experiments, several 
projects of the different level are necessary in practice. These projects involve the virtual management information system, small real application system and business projects in enterprises.

Since the new teaching mode emphasizes practice, the class hours need to make some adjustments. The theoretical class hours should be reduced, while the experimental class hours should be increased. In practical teaching activities, several students form a group to complete a project.

Teaching content. According to the idea of project-driven teaching, we firstly determine the teaching content in the database application course. If DBMS is Oracle in this course, the teaching content involves two items in Table1.

Table1 Teaching Contents

\begin{tabular}{ccc}
\hline Teaching method & Teaching contents & Teaching hours \\
\hline Theory teaching & $\begin{array}{c}\text { Oracle database server installation, tools of Oracle, } \\
\text { architecture of Oracle, SQL and PL/SQL } \\
\text { Practice teaching }\end{array}$ & Four weeks \\
& $\begin{array}{c}\text { Virtual MIS、 real projects business projects in } \\
\text { enterprises }\end{array}$ & Eight weeks
\end{tabular}

Because students have learned the principle of relational database in the past, teachers only need to teach the basic knowledge of Oracle in the theoretical teaching activities. So the theoretical class hours are less than the experimental class hours in this course. The latter is about two times of the former.

The practical teaching plays an important role in this course. The process of practical teaching is divided into two phases. First, students do the validating experiment. These experiments are related to the basic knowledge. The second is the course project. The course project is connected with the previous experiments. Now multiple level projects will be developed. There are three level projects as follows:

At the first level, the projects are virtual small management information systems, such as the library management system. The systems are not real projects. Teachers can specify a number of topics and students choose one to complete. This level of the projects is lowest, and it is not difficult. So each student is required to design and develop at least one MIS. Through these projects, students master the basic skills of database application system development.

At the second level, the projects are real small application systems. It may be teachers' research projects, engineering projects in enterprises or others, such as the exam score quality analysis system. Different from virtual projects, these systems will be put into use. So the system requirement analysis should be detailed and true. The projects of this level are more difficult than the first ones. Students develop the systems freely in groups of three or four persons. In the process of development, each student plays a different role. Someone is a project manager, someone is a software engineer and someone is a test engineer. They work together to complete the whole project. In this way, students understand the real process of software development and develop their self-study abilities.

At the third level, schools and companies can cooperate to carry out some business projects. Teachers can look for some companies. The business of companies covers Oracle database application development and management. Some students do an internship in these companies for about two weeks to one month. During the internship, they join a project team and work together with developers of the company. In an excellent team, students are able to learn a lot from those experienced developers. And they are familiar with the corporate culture and business process. In addition, schools can hire technical staff in companies as part-time teachers. It solves the problem of some full-time teachers' lack of sufficient work experiences.

In teaching process, the projects of different levels are implemented according to the following rules. Every student must finish at least one virtual MIS. Then the real application system is optional. Every student decides to do or not do according to his/her own knowledge. Finally, some students enter enterprises to participate in the business projects. The others stay in school. Experienced developers of enterprises train them to simulate the development of business projects.

Teaching process. According to the teaching content, there are following steps in the whole 
teaching process.

(1)Teachers teach the knowledge and theory about Oracle in class.

In the theoretical teaching, the main knowledge units include Oracle database server installation, tools of Oracle, architecture of Oracle, SQL and PL/SQL.

(2) Each student chooses a project and determines his/her role and task.

Students can be combined freely and three or four people form a team. In each team, all members elect a project manager. The project manager is responsible for overall control of the development process. In the phase of requirement analysis, team members discuss together and decide the development plan of the project. Then the project manager assigns work to each team member. All team members can take turns system design, coding or testing. It makes each student play a different role in the development process. This ensures that everyone can learn various techniques.

(3)The teacher follows up the whole development process and guides students at the appropriate time.

As student learned the basic principles of database before, teachers only need to explain the characteristics of Oracle, such as PL/SQL statements. Then students consult documents and materials to study independently. As a mentor, teachers help students solve some difficult problems. Teachers and students often communicate via E-mail, teaching websites and small meetings. At the critical stage of the project, teachers check the partial results, correct the deviation, and encourage student to cooperate with each other better.

The above second step and third step are repeated in different level projects until the end of all projects.

(4)The teacher evaluates each student.

At the end of the course, the teacher gives each student the overall mark. The completion of the project is an important criterion for giving marks. Firstly, students' practical skills are evaluated. In each team, every student states what he/she has done. Then the teacher asks questions about the student's statement. After the student answers the questions, the teacher evaluates his/her practices according to the following criteria. How does the tasks finish? Are the questions answered correctly? Secondly, every student must write a summary report about the development of project. The teacher will give a score about the report.

Teaching effect. After we adopt the new teaching mode in the class of 2014, their study interest and activeness are better than other class. Students are no longer satisfied with the learning in the classroom. After class, they actively discuss the difficult knowledge and unresolved problems. The results show that the new teaching mode increases students' comprehensive abilities. In addition, students' new ideas make teachers think more about teaching contents. Teaching benefits teachers as well as students.

\section{Conclusion}

The multi-level project driven teaching mode improves teaching efficiency. But it can't replace other teaching methods, especially teaching in classroom. By classroom instruction, teachers can explain the key points and difficulties in detail. Teachers need to properly handle the relationship between the new teaching mode and classroom teaching. Besides, we can't ignore other teaching methods, such as teaching websites.

\section{References}

[1] Liu Youyao, Jiang Lin, Du Huimin, Zhang Liguo, Gong Jiamin, Liu Jihong, Research and Practice on Nurturing Innocative Talents in Engineering Aplicaiton, Research in Higher Education of Engineering,2015,5

[2] Li Wen, Huang Wen, Yin Xiangdong, Wu Tiebin, Reform and Practice on Project-driven Teaching of Digital Logic Experiment under the IACI-CDIO Idea, Research and Exploration in Laboratory, 2014,33(6) 
[3] Wang Junshe, Zhang Xiaoming, Zhang Jianyan, Exploration of improving undergraduate's practical ability in information majors, Experimental Technology and Management,2014,31(2)

[4] Jiang Dazhi, Sun Haojun, On CDIO-Based Active Project-driven Learning Method, Research in Higher Education of Engineering,2012,4

[5] Zhao Dandan, Li Xizuo, Song Haiyu, Wang Lingfen, Practice of project-driven teaching mode in computer personnel fostering, Experimental Technology and Management, 2011,28(7) 